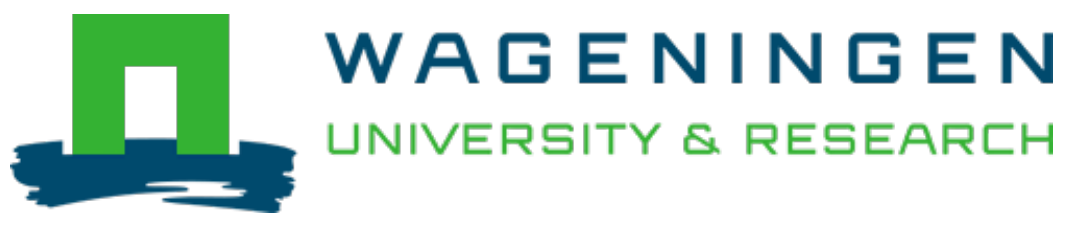

\title{
Exploring the boundaries of the passive greenhouse in Jordan: A modelling approach
}

\author{
Acta Horticulturae \\ Baeza Romero, E.J.; Os, E.A.; Salm, C.; Tsafaras, I.; Blok, C. \\ https://doi.org/10.17660/ActaHortic.2020.1268.6
}

This article is made publicly available in the institutional repository of Wageningen University and Research, under the terms of article $25 \mathrm{fa}$ of the Dutch Copyright Act, also known as the Amendment Taverne. This has been done with explicit consent by the author.

Article 25 fa states that the author of a short scientific work funded either wholly or partially by Dutch public funds is entitled to make that work publicly available for no consideration following a reasonable period of time after the work was first published, provided that clear reference is made to the source of the first publication of the work.

This publication is distributed under The Association of Universities in the Netherlands (VSNU) 'Article $25 \mathrm{fa}$ implementation' project. In this project research outputs of researchers employed by Dutch Universities that comply with the legal requirements of Article $25 \mathrm{fa}$ of the Dutch Copyright Act are distributed online and free of cost or other barriers in institutional repositories. Research outputs are distributed six months after their first online publication in the original published version and with proper attribution to the source of the original publication.

You are permitted to download and use the publication for personal purposes. All rights remain with the author(s) and / or copyright owner(s) of this work. Any use of the publication or parts of it other than authorised under article $25 \mathrm{fa}$ of the Dutch Copyright act is prohibited. Wageningen University \& Research and the author(s) of this publication shall not be held responsible or liable for any damages resulting from your (re)use of this publication.

For questions regarding the public availability of this article please contact openscience.library@,wur.nl 


\title{
Exploring the boundaries of the passive greenhouse in Jordan: a modelling approach
}

\author{
E.J. Baeza Romero, E.A. van Os, C. van der Salm, I. Tsafaras and C. Blok
}

Wageningen University \& Research, Greenhouse Horticulture, Droevendaalsesteeg 1, 6708 PB Wageningen, The Netherlands.

\begin{abstract}
Greenhouses are expanding fast in arid and semi-arid regions, among other reasons, because of the water savings that can be realized compared to open field cultivation. However, it is difficult for growers to recognize the optimum greenhouse design. Many competing aspects must be weighed against each other such as the structure, the cover and the climate control equipment. Obviously, the optimum design must be tailored for each specific crop and growing cycle and availability of resources (land, water, energy, labor, etc.). Simulation models can assist in this process, saving time and money. Wageningen University \& Research, BU Greenhouse Horticulture has developed the Adaptive Greenhouse Methodology. It combines the use of greenhouse climate and resources simulation models, with crop growth and economic models, to solve the problem of designing the optimum greenhouse for each specific scenario in the world. In the present work we present the results of the application of this methodology to the specific case of the production of greenhouse soilless tomato in two regions in Jordan in the mid tech range: the highlands and the Jordan Valley. Results show that different mid tech designs could potentially provide yield levels of up to 35 and $27 \mathrm{~kg} \mathrm{~m}^{-2}$ in the Highlands and the Jordan Valley, respectively. The final design is similar in the two locations.
\end{abstract}

Keywords: cooling, whitewash, fogging, tomato, shading

\section{INTRODUCTION}

Jordan has a large horticulture sector: the total area of crops is around 275,000 ha, of which 135,000 ha are fruit and vegetables. Around 4000 ha of the 135,000 ha are simple greenhouses (Jordan Department of Statistics, 2018), both low and high tunnels covered with polyethylene. The two main agricultural production areas are the Jordan Valley and the Highlands:

- The Jordan Valley (located 200-400 m below sea level) has fertile soils and a very privileged climate with long day hours and temperatures which are a few degrees higher than that of the surrounding regions year round. In the winter the Jordan Valley (JV) is the only region in the country producing fresh products, but the summer in JV is too warm to cultivate. This is the largest greenhouse region in the country (approximately 3,500 ha);

- The Highlands (HL) have and average altitude ranging from $600 \mathrm{~m}$ in the north to $1,000 \mathrm{~m}$ in the middle and 1,500 $\mathrm{m}$ in the south. HL get the highest amount of rain fall and the winter temperatures are low and limiting cultivation during this period. Therefore, the highlands complement vegetable production to the JV during the summer.

In both, the JV and in the HL, the large majority of growers use very simple individual plastic tunnel greenhouses of $420 \mathrm{~m}^{2}(52.5 \times 8 \mathrm{~m}$; Figure 1). These tunnels do not have any means of climate control other than a very limited natural ventilation capacity, which is achieved by opening the front and back of the tunnel. Improving the ventilation can be cheaply done by making a slit of $20 \mathrm{~cm}$ after each strip of covering foil. Some growers also spread mud over the tunnels to create a very low uniform shading when solar radiation levels become very high (Figure 1). Cultivation in these tunnels is usually in the soil, with relatively poor water 
use efficiency which is a drawback in a country like Jordan, where water availability is an important limiting factor for agricultural operations. Jordan is one of the four most water stressed countries in the world (Fileccia et al., 2015).

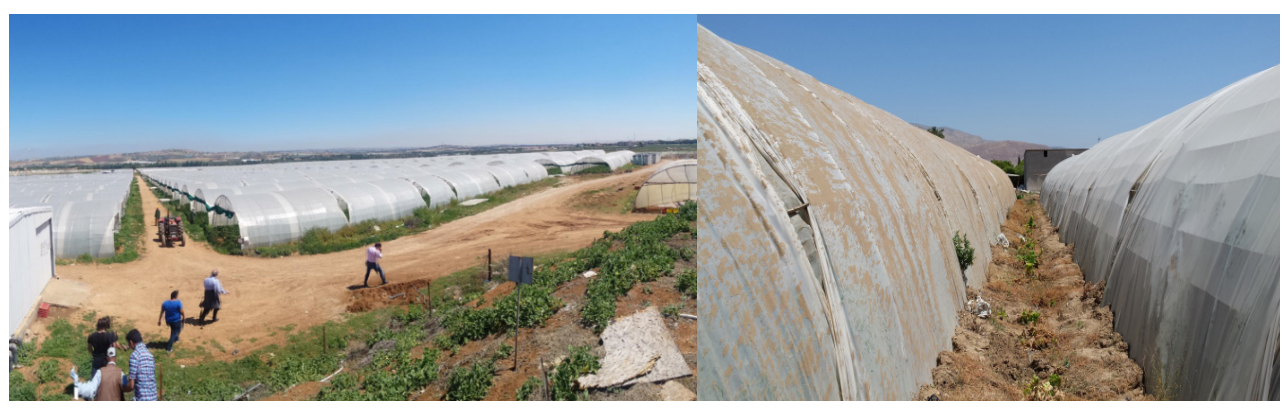

Figure 1. Typical Jordanian single tunnel greenhouse with small slits for ventilation and mud over the roof for shading.

In order to increase the water use efficiency in Jordan greenhouses, growers must start switching to hydroponic cultivation, collecting and reusing drain water and collecting and using rain water to improve water quality (Blok et al., 2017). Furthermore, they need to improve their productivity to increase the feasibility. To increase the productivity and feasibility, new greenhouse designs with some possibility of climate control need to be introduced.

Choosing the optimum design for a certain location is a complex problem with many variables (climate, crop, growing cycle, availability of resources, etc.). Vanthoor (2011) proposed the adaptive greenhouse methodology to design a protected cultivation system that best satisfies the local conditions in the region considered, based on the coupling of different well validated mathematical models: a) a model capable of simulating the greenhouse microclimate for a large number of technological combinations; b) a crop growth model capable of simulation dry matter production, using as input the predicted microclimate; and c) an economic model, to evaluate the profit obtained with each option. This methodology has been used by different authors to evaluate different greenhouse technological packages for different world locations such as Turkey (Tuzel et al., 2017), Mexico (Elings et al., 2013) and Taiwan (Hemming et al., 2014).

In the present work, the adaptive greenhouse approach has been used to obtain the optimum greenhouse design for the production of export quality tomato in the two main growing regions in Jordan: the Jordan Valley and the Jordan Highlands. Only the yield and the water use efficiency have been used as criteria as the economic analysis has not been included to limit the length of the paper.

\section{MATERIALS AND METHODS}

\section{Climate data}

For the JV a complete data set was available from a meteorological station from NCARE in Deir Alla, for year 2015. For the HL, data were retrieved from Amman airport for several years of which 2012 was chosen, as it was the warmest year (in order to evaluate designs for the most limiting summer conditions). Table 1 summarizes some of the most relevant values.

\section{Greenhouse climate simulation model}

For the simulation of the greenhouse microclimate and the use of different resources (water, energy, etc.) the model KASPRO (De Zwart, 1996) has been used. This model is built from modules describing the physics of mass and energy transport in the greenhouse enclosure, coupled with a large number of modules that simulate various greenhouse climate control equipment. The model can also realistically mimic different climate control strategies. Natural ventilation is simulated in Kaspro using the ventilation model developed by de 
Jong (1990) for large multispan greenhouses.

Table 1. Summary of the most important climate variables in the years used for the two analyzed climate regions: Deir Alla (2015) and Amman (2012). Winter is December through February and summer June through August in all cases.

\begin{tabular}{lcccccc}
\hline & \multicolumn{3}{c}{ Deir Alla (J. Valley)-2015 } & \multicolumn{3}{c}{ Amman (Highlands)-2012 } \\
\cline { 2 - 7 } & Winter & Summer & Year & Winter & Summer & Year \\
\hline Sun radiation $\left(\mathrm{MJ} \mathrm{m}^{-2}\right.$ day $\left.^{-1}\right)$ & 11.4 & 27.4 & 18.9 & 8.1 & 17.3 & 12.9 \\
Mean temperature $\left({ }^{\circ} \mathrm{C}\right)$ & 16.8 & 33.2 & 25.2 & 8.2 & 26.7 & 18.6 \\
Average $\mathrm{T}_{\max }\left({ }^{\circ} \mathrm{C}\right)$ & 21.6 & 40 & 31.1 & 12 & 32.5 & 23.7 \\
Average $\mathrm{T}_{\min }\left({ }^{\circ} \mathrm{C}\right)$ & 11 & 25.6 & 18.2 & 4.9 & 21.9 & 14.1 \\
Mean R.H. $(\%)$ & 71.8 & 56.1 & 59.4 & 64.8 & 37.1 & 47.5 \\
Mean wind velocity $\left(\mathrm{m} \mathrm{s}^{-1}\right)$ & 1.3 & 1.2 & 1.2 & 3.1 & 3 & 2.7 \\
\hline
\end{tabular}

\section{Tomato crop growth model}

The simulated microclimate has been coupled to the tomato crop growth model proposed by Vanthoor (2011). The selected model, based on the photosynthesis model of Goudriaan and Van Laar (1994), can also account for the effect supra and sub-optimal temperatures on photosynthesis and on production. This is achieved with growth inhibition functions. In the present work we have used an upper boundary for unhampered instantaneous growth of $28^{\circ} \mathrm{C}$ and for the $24 \mathrm{~h}$ mean, of $22^{\circ} \mathrm{C}$. Equally, the lower boundary for unhampered instantaneous growth was 14 and $18^{\circ} \mathrm{C}$ for the $24 \mathrm{~h}$ mean.

\section{Scenarios simulated}

\section{Effect of improved natural ventilation (both locations).}

In a first step, two basic greenhouse structures covered with a standard PE film cover have been compared, which do not include any means of climate control other than natural ventilation and shading by whitewash during part of the growing cycle (Figure 2): a) a multi span greenhouse with a single fixed roof vents (always open) on each span and b) a multi span greenhouse with a double automated roof vent on each span. Both greenhouses share the same basic geometrical characteristics, except for the ventilation area and its automation (Table 2).

Table 2. Main geometrical parameters of the simulated greenhouses.

\begin{tabular}{lcc}
\hline Parameter & Value & Units \\
\hline Greenhouse area & $4992(48 \times 104)$ & $\mathrm{m}^{2}$ \\
Central path width & 3 & $\mathrm{~m}$ \\
Gutter height & 3 & $\mathrm{~m}$ \\
Span width & 9.6 & $\mathrm{~m}$ \\
Roof slope & 22 & $\mathrm{deg}$ \\
Covering material & $\mathrm{PE} \mathrm{film}$ & \\
Leakage & $1.60 \mathrm{E}-04$ & $\mathrm{~m}^{3} /\left[\left(\mathrm{m}^{2} \mathrm{~s}\right) /\left(\mathrm{m} \mathrm{s}^{1}\right)\right]$ \\
Vent length & 48 & $\mathrm{~m}$ \\
Vent height (fixed roof vent type) & 1.2 & $\mathrm{~m}$ \\
Vent height (double roof vent type) & 1.6 & $\mathrm{~m}$ \\
Ventfloor ratio (fixed vent type) & 7.5 & $\%$ \\
Ventfloor ratio (double controlled vent type) & 20 & $\%$ \\
\hline aAn anti-trip insect proof screen has been simulated which reduces ventilation area by $40 \%$.
\end{tabular}




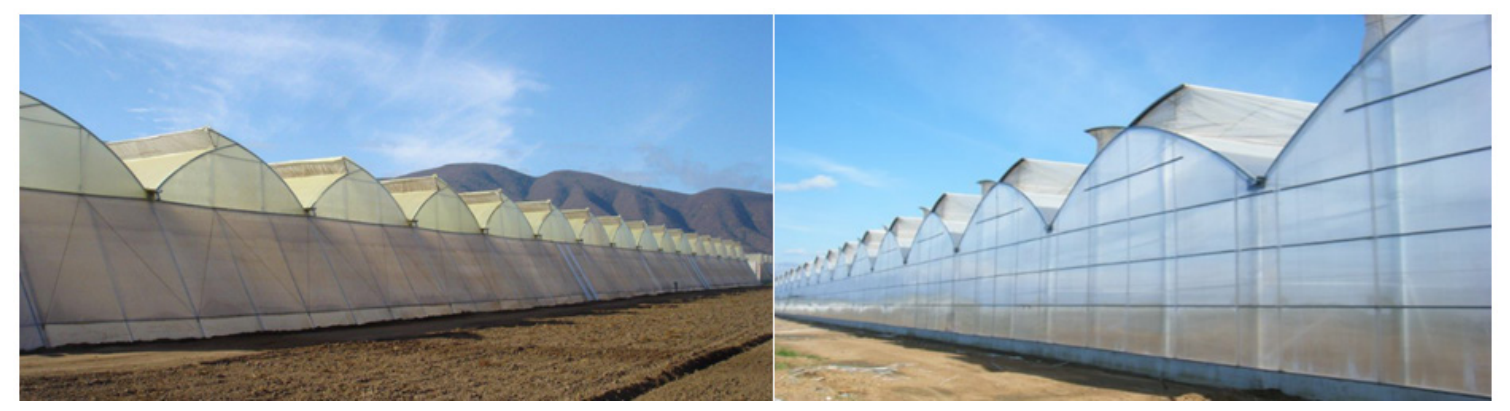

Figure 2. The two types of greenhouse structures simulated: multi span greenhouse with a single fixed roof vents (left); multi span greenhouse with double automated roof vent on each span (right).

The simulated growing cycles went from October 1 until June 15 in the Jordan Valley and from March 1 until November 30 in the Highlands. The simulated PE film cover has a hemispherical light transmission coefficient of $80 \%$ and a transmission coefficient to thermal infrared radiation of $35 \%$ (emissivity of $60 \%$ ). In the simulations for both locations, a whitewash applied on April 1 with a shading factor of 50\% was simulated. In the Highlands this whitewash was removed on September 15 and in the Jordan Valley it stayed until the crop cycle finished in June.

The best performing passive greenhouse structure (of these two) was selected to perform simulations in which different climate control equipment was simulated.

\section{Improved shading management (both locations).}

An internal mobile shading screen with $40 \%$ aluminized fraction and $60 \%$ open fraction was simulated. The management of the screen was between April 1 to July 15: it was closed between 60 and $75 \%$ between 500 and $650 \mathrm{~W} \mathrm{~m}^{-2}$ and fully closed whenever solar radiation exceeded $800 \mathrm{~W} \mathrm{~m}^{-2}$. Between July 15 and September 15 it would be fully closed above $500 \mathrm{~W}$ $\mathrm{m}^{-2}$ and after September 15 it would fully close if radiation exceeded $1000 \mathrm{~W} \mathrm{~m}^{-2}$. The screen was also closed at night whenever outside temperature was below $16^{\circ} \mathrm{C}$.

\section{Use of a thermal screen to improve night time climate during the winter period (Jordan Valley).}

A highly aluminized thermal screen was simulated $(80 \%$ aluminum and $20 \%$ closed transparent stripes). The screen was completely closed whenever outside temperature decreased below $15^{\circ} \mathrm{C}$ and solar radiation below $5 \mathrm{~W} \mathrm{~m}^{-2}$.

\section{Use of evaporative cooling by means of a high pressure fog system (both locations).}

A fog system with a capacity of $400 \mathrm{~g} \mathrm{~m}^{-2} \mathrm{~h}^{-1}$ was simulated, which was activated whenever greenhouse temperature exceeded $27^{\circ} \mathrm{C}$ and/or relative humidity decreased below $70 \%$. For the simulations with the fog system no shading was used (no whitewash nor shading screen).

\section{RESULTS AND DISCUSSION}

\section{Effect of improved natural ventilation (both locations)}

The effect of increasing the ventilation area and the possibility to control the vents has a clear positive effect on the microclimate on both locations (Table 3). The improved ventilation decreases largely the amount of hours that the greenhouse air temperature, but especially crop temperature, both exceed a threshold value of $28^{\circ} \mathrm{C}$, above which photosynthesis in tomato is affected. It also allows for an important decrease of the hours in which relative humidity exceeds $90 \%$, conditions which may favor condensation on the crop and possible attack of pathogens. Finally, it also increases the average daytime values of in greenhouse carbon dioxide levels, enhancing crop photosynthesis. Altogether, these positive 
effects have a clear positive effect on the predicted yield, which is higher in the improved ventilation greenhouse (Figure 3; Table 4). In both cases, main differences occur, as expected, during the warmer months of the cycle. This is in accordance with the results of Baeza et al. (2005) and Short and Lee (2002), who concluded that the ventilation rate increases with the opening size of a greenhouse with roof vents alone. Stanghellini and de Zwart (2015) also found and improved microclimate and yield by adding a controller to the greenhouse vents for the Agadir region.

Table 3. Summary of hours above and below some critical physiological thresholds for production in tomato and average diurnal.

\begin{tabular}{lcccc}
\hline Greenhouse type & $\begin{array}{c}\text { Hours air } \\
\text { temp. }>\mathbf{2 8} \mathbf{0}^{\circ} \mathbf{C}\end{array}$ & $\begin{array}{c}\text { Hours } \\
\mathbf{R H}>\mathbf{9 0 \%}\end{array}$ & $\begin{array}{c}\text { Average diurnal } \mathbf{C O}_{2} \\
\text { concentration (ppm) }\end{array}$ \\
\hline Highlands & Fixed roof vent type & 757 & 1186 & 350 \\
& Controlled double vent type & 664 & 655 & 366 \\
\hline Jordan Valley & Fixed roof vent type & 1396 & 4409 & 330 \\
& Controlled double vent type & 1042 & 3613 & 367 \\
\hline
\end{tabular}

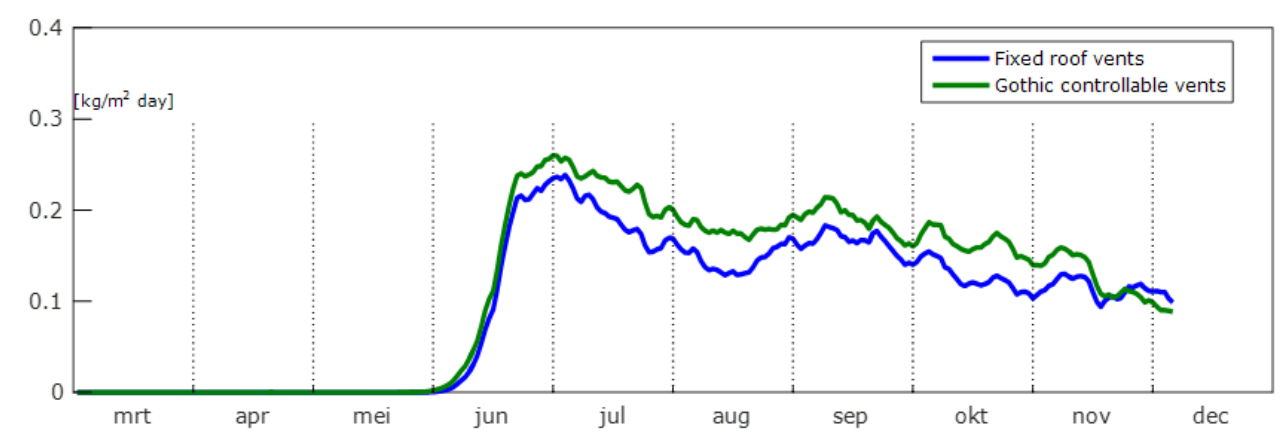

a) Highlands

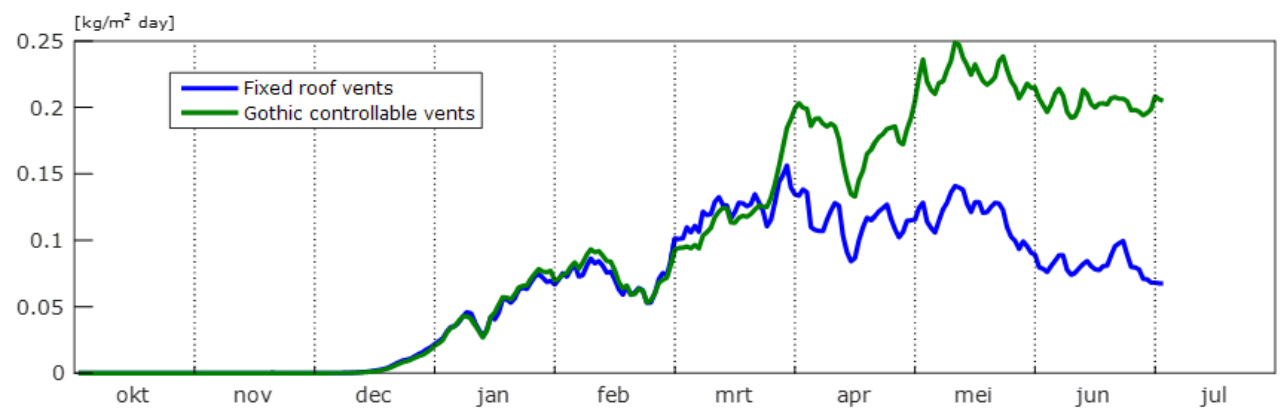

b) Jordan Valley

Figure 3. Evolution of daily tomato dry matter production $\left(\mathrm{kg} \mathrm{m}^{-2}\right)$ along the growing cycle for greenhouses with fixed roofs and with gothic controllable for the two simulated locations.

Altogether, the greenhouse with improved natural ventilation was selected as the basic structure for which simulations with the aforementioned climate control equipment are done.

\section{Improved shading management (both locations)}

In the highlands, the use of an internal mobile shading screen allows for a larger $(16.2 \%$ 
higher) integral of PAR radiation available for the crop (5041 $\mathrm{MJ} \mathrm{m}^{-2}$ ) than for the reference with a whitewash during high radiation period (4335 $\left.\mathrm{MJ} \mathrm{m}^{-2}\right)$. Also in the Jordan Valley, the PAR integral under the shading screen is also $12.6 \%$ higher (4797 vs. $4260 \mathrm{MJ} \mathrm{m}^{-2}$ ) under the shading screen than under the reference. However, in the JV this extra amount of light cannot be used efficiently by the crop because in the average maximum temperatures are higher and consistently above the threshold during the warmer months (Table 4). The maximum differences, in the growing cycles of the JV and HL, are observed in the month of June, with lower maximum temperatures under the shading screen than under the reference in the Highlands, being the opposite in the Jordan Valley. The mean of the maximum values of ventilation rate and temperatures for this month in the Jordan Valley for the shading screen scenario are $168.7 \mathrm{~m}^{3} \mathrm{~m}^{-2} \mathrm{~h}^{-1}$ and $37.2^{\circ} \mathrm{C}$, respectively. In the Highlands these values are 413.6 $\mathrm{m}^{3} \mathrm{~m}^{-2} \mathrm{~h}^{-1}$ and $30.5^{\circ} \mathrm{C}$. This can be explained by the fact that the HL are much windier than the JV (Table 1). García-Balaguer et al. (2017) also observed an increase in yield (25\%) when using of the same type of shading screen for a tomato crop, in relation to a whitewash. In our simulation for HL, the increase in yield was lower (14\%). However, the trial of García-Balaguer et al. (2017) was performed in a smaller greenhouse which combined sidewall and roof vents, thus a much larger ventilation capacity, and the growing cycle ended just before the summer. Therefore, they had a lower number of screen hours and an increase (\%) of incident PAR of $35 \%$, much larger than in our case.

Table 4. Summary of the final potential tomato yields $\left(\mathrm{kg} \mathrm{m}^{-2}\right)$ estimated by the model for each scenario.

\begin{tabular}{lcc}
\hline \multirow{2}{*}{ Greenhouse fitting } & \multicolumn{2}{c}{ Yield $\left(\mathbf{k g ~ m}^{-2}\right)$} \\
\cline { 2 - 3 } & Highlands & Jordan Valley \\
\hline Fixed roof vents (whitewash) & 26.3 & 17 \\
Improved controlled ventilation (whitewash) & 31.1 & 26.2 \\
Use of a shading screen instead of whitewash & 35.5 & 25.6 \\
Energy screen at night (whitewash) & - & 26.7 \\
Fog (no whitewash) & 39.1 & 27.5 \\
\hline
\end{tabular}

It could be argued, that for the Jordan Valley, an external mobile shading screen would have resulted better than the whitewash and the internal shading screen, as observed by Lorenzo et al. (2003). However, the price of these screens is quite high and in the Jordan Valley, a very arid region, the screen would have to be washed very often.

The final conclusion is to recommend the use of an internal mobile shading screen in the Highlands, but not in the Jordan Valley, where simulations show that whitewash is a better option.

\section{Use of a thermal screen to improve night time climate during the winter period (Jordan Valley)}

The use of a thermal screen does not show a very important positive effect on the estimated final yield (Table 4). However, the model used is unable to predict, for instance, the incidence of diseases, which may have an effect on the final marketable yield. In this way, the simulated thermal screen has helped maintaining higher minimum canopy temperatures during the winter period in the Jordan Valley (on average, $1.5^{\circ} \mathrm{C}$ higher) than the reference, which in turn, has limited the amount of hours that the crop was wet due to condensation (1471 $\mathrm{h}$ with the screen and 1661 in the reference). This result agrees with the finding of Montero et al. (2013), who also observed similar positive effects of using a thermal screen in a mild winter climate region.

Given the high risk of incidence of fungal diseases in passive greenhouses in mild winter climate regions (Baptista et al., 2012), the use of a thermal screen would be very advisable not only for increasing the minimum temperature in winter, but also to prevent condensation related problems caused by night time radiation losses. 


\section{Use of evaporative cooling by means of a high pressure fog system (both locations)}

In the Highlands, where the growing cycle takes place largely during the summer, the use of evaporative cooling shows an excellent yield performance as an alternative to whitewash. However, Meca et al. (2007) compared the performance of a fog system vs. whitewash for Mediterranean conditions, and they observed more than double amount of non-marketable fruits under the fog system compared to whitewash or with an internal mobile shading screen. However, comparison was made for a poorly ventilated "parral" type greenhouse, thus, efficiency of the fogging system in decreasing air temperature was probably limited. The model predicts an amount of water used for fogging of $402 \mathrm{~L} \mathrm{~m}^{-2}$ (half of the amount transpired by the crop, which was $816 \mathrm{~L} \mathrm{~m}^{-2}$ ) and in a fog system, this water must be of excellent quality. In a country like Jordan, with a large water availability problem, this value is large enough to consider the convenience of the use of the fog system. Therefore, it could be argued whether or not the use of the fog system is justified.

In the Jordan Valley, the advantage of using a fog system in terms of yield increase is much lower (Table 4), mostly because the growing cycle does not include the summer. Indeed, the use of water is much lower than for the highlands $\left(194.6 \mathrm{~L} \mathrm{~m}^{-2}\right.$, whereas the total amount transpired by the crop was $570 \mathrm{~L} \mathrm{~m}^{-2}$ ). However, a fog system would allow for the growing cycle to be extended, either by making an earlier transplant, or by extending cultivation through the summer.

\section{CONCLUSIONS}

\section{Highlands}

The simulations indicate that for the Highlands, the best combination would be the use of a multispan greenhouse with regulated high ventilation capacity, an internal mobile shading screen. Alternatively, the fog system could be used instead of the shading screen, but only if there is enough high quality water available. However, given the scarcity of and high price of water in the Highlands, the use of a fog system should be prevented. The use of a shading screen would allow to obtain a tomato yield well above $30 \mathrm{~kg} \mathrm{~m}^{-2}$.

\section{Jordan Valley}

For the Jordan Valley, simulations show that the greenhouse should be the same type recommended for the Highlands, combined with the use of a highly aluminized ( $>80 \%$ aluminum) thermal screen and a temporary whitewash. A fog system could be added only if the grower wishes to extend the growing cycle into the warmer summer months, when shading is not sufficient to maintain temperatures below the values required to grow tomato successfully (data not shown) but only growers with RO equipment could afford its use.

The proposed greenhouses are being constructed now. This paper is the introduction to new Jordan horticultural development.

\section{ACKNOWLEDGEMENTS}

This research is part of the HAED project (Creating food security and employment for Syrian refugees in Jordan) funded by the Dutch Ministry of Foreign Affairs.

\section{Literature cited}

Baeza, E.J., Pérez-Parra, J., and Montero, J.I. (2005). Effect of ventilator size on natural ventilation in parral greenhouse by means of CFD simulations. International symposium on greenhouse cooling: methods, technologies and plant response. Acta Hortic. 691, 465-472 https://doi.org/10.17660/ActaHortic.2005.691.56.

Baptista, F., Bailey, B.J., and Meneses, J.F. (2012). Effect of nocturnal ventilation on the occurrence of Botrytis cinerea in Mediterranean unheated tomato greenhouses. Crop Prot. 32, 144-149 https://doi.org/10.1016/j.cropro.2011. 11.005 .

Blok, C., van Os, E., Daoud, R., Waked, L., and Ala'a, H. (2017). Hydroponic Green Farming Initiative. http://edepot.wur.nl/426168.

de Jong, T. (1990). Natural ventilation of large multi-span greenhouses. Ph.D. thesis (Wageningen, The Netherlands: Wageningen University). 
De Zwart, H.F. (1996). Analysing energy-saving options in greenhouse cultivation using a simulation model. Ph.D. thesis (Wageningen, The Netherlands: Agricultural University).

Elings, A., Speetjens, S.L., and Garcia Victoria, N. (2013) Greenhouse designs for Mexico. Aguascalientes, Querétaro and Sinaloa. http://edepot.wur.nl/302763.

Fileccia, T., Hovhera, V., Punda, I., and Manzo, S. (2015). Jordan: Water along the food chain. http://www.fao.org/ 3/a-i4608e.pdf.

García-Balaguer, M.L., Sánchez-Guerrero, M.C., Medrano, E., Baeza, E.J., Sánchez-González, M.J., Porras, M.E., Giménez, M., and Lorenzo, P. (2017). Mobile shading versus whitewashing: evaluation of the agronomic response of a tomato crop. Acta Hortic. 1170, 959-966 https://doi.org/10.17660/ActaHortic.2017.1170.123.

Goudriaan, J., and Van Laar, H.H. (1994). Modelling Potential Crop Growth Processes. Textbook with Exercises (Dordrecht: Kluwer Academic Publishers), pp.238.

Hemming, S., Speetjens, S.L., Wang, D., and Tsay, J.R. (2014). Greenhouse design for vegetable production in subtropical climate in Taiwan. Acta Hortic. 1037, 65-74 https://doi.org/10.17660/ActaHortic.2014.1037.4.

Jordan Department of Statistics. (2018). Agricultural Statistics 2015. http://dosweb.dos.gov.jo/productcategory/agricultural-statistics/ (accessed December 14, 2018).

Lorenzo, P., Sánchez-Guerrero, M.C., Medrano, E., García, M.L., Caparrós, I., and Giménez, M. (2003). External greenhouse mobile shading: effect on microclimate, water use efficiency and yield of a tomato crop grown under different salinity levels of the nutrient solution. Acta Hortic. 609, 181-186 https://doi.org/10.17660/ActaHortic. 2003.609.24.

Meca, D., López, J.C., Garrido, J.C., Baeza, E., Pérez-Parra, J., and Zaragoza, G. (2007). A comparison of three different cooling systems in parral type greenhouses in Almería. Span. J. Agric. Res. 5 (3), 285-292 https://doi.org/10.5424/ sjar/2007053-5341.

Montero, J.I., Muñoz, P., Sánchez-Guerrero, M.C., Medrano, E., Piscia, D., and Lorenzo, P. (2013). Shading screens for the improvement of the night-time climate of unheated greenhouses. Span. J. Agric. Res. 11 (1), 32-46 https://doi. org/10.5424/sjar/2013111-411-11.

Short, T.H., and Lee, I.B. (2002). Temperature and airflow predictions for multi-span naturally ventilated greenhouse. Acta Hortic. 578, 141-152 https://doi.org/10.17660/ActaHortic.2002.578.16.

Stanghellini, C., and de Zwart, F. (2015). Adaptive greenhouse design: what is the best to grow tomato in Northern Africa? http://edepot.wur.nl/386128.

Tuzel, Y., de Zwart, H.F., Sapounas, A., Hemming, S., and Stanghellini, C. (2017). Improvement of greenhouse climate control in Mediterranean conditions: a case study from Turkey. Acta Hortic. 1170, 889-896 https://doi.org/10. 17660/ActaHortic.2017.1170.114.

Vanthoor, B.H.E. (2011). A model-based greenhouse design method. Ph.D. thesis (Wageningen, The Netherlands: Wageningen University). 